\title{
ESCHERICHIA COLI ANTIBODIES IN OPSONISATION AND PROTECTION AGAINST INFECTION
}

\author{
Willemien C. van Dijk, H. A. Verbrugh, \\ MariJke E. Van ERne-van der Tol, R. Peters \\ AND J. VERHOEF \\ Laboratory of Microbiology, State University Utrecht, Catharijnesingel 59, 3511 GG \\ Utrecht, The Netherlands
}

\begin{abstract}
Summary. The opsonic and protective capacities of rabbit antisera against Escherichia coli $\mathrm{O}, \mathrm{K}$ and core-glycolipid cell-wall antigens were compared with specific antibody titres as measured by agglutination and enzyme-linked immunosorbent assay. Anti-O antisera were opsonic and protective against two noncapsulate strains. Only anti-K antisera were opsonic and protective against a $\mathrm{K}$-antigen-containing strain. In a mouse model anti-core-glycolipid antiserum was not protective against challenge even by a strain bearing only core glycolipid.
\end{abstract}

\section{INTRODUCTION}

Strains of Escherichia coli with K-capsular antigens have been regarded as virulent because of the higher incidence of their involvement in invasive infections (McCabe et al., 1975; van Dijk et al., 1979a). Strains of E. coli bearing the $\mathrm{K} 1$ capsular antigen may cause acute pyelonephritis in children (Kaijser, 1973; Kaijser et al., 1977) and meningitis in neonates (Robbins et al., 1974). The most common K-antigen types found in isolates from patients with septicaemia are different from those common in acute pyelonephritis or neonatal meningitis. Many of the former have untypable $\mathrm{K}$ antigens (McCabe et al., 1978). The virulence of the strains containing K antigen seems to be related to the antiphagocytic activity of the $\mathrm{K}$ antigen. Whereas antibodies are not required for the phagocytosis of noncapsulate strains, specific antibodies against $\mathrm{K}$ antigen appear to be necessary for optimal opsonisation of the strains bearing $\mathrm{K}$ antigen (Kaiser, Holmgren and Hanson, 1972; Kaijser and Ahlstedt, 1977; Welch and Stevens, 1979; Welch et al., 1979). Several studies have shown that these opsonic anticapsular antibodies are protective in vivo (Wolberg and DeWitt, 1969; Kaijser and Ahlstedt, 1977; Kaijser et al., 1977). However, in other studies (Wolberg and DeWitt, 1969) antisomatic O antibodies, raised against the O-antigenic polysaccharide side chains of the lipopolysaccharide were 
opsonic and protective for a strain containing $\mathrm{K}$ antigen. In addition, several investigators have reported that antisera raised in horses and rabbits against rough mutants of Enterobacteriaceae (strains with lipopolysaccharides lacking O-antigenic side chains) and containing antibodies against the core-glycolipid antigen, could passively transfer broad-spectrum protection against parenteral challenge with smooth strains (with O-antigenic side chains) of Enterobacteriaceae (McCabe, 1972; Ziegler et al., 1973; Young, Stevens and Ingram, 1975). These antibodies appear to act primarily as anti-endotoxic antibodies rather than as opsonins (Braude, Douglas and Davis, 1973). In contrast, $\mathrm{Ng}$ et al., (1976) and Greisman, Du Buy and Woodward (1978) were unable to confirm the protective capacity of coreglycolipid antibodies against challenge with smooth gram-negative bacteria.

Because of the controversy about the role of anti-K-, anti-O- and anti-core-glycolipid antibodies in opsonisation and protection against infection by $E$. coli, the protective and opsonic capacities of antisera raised in rabbits against $E$. coli strains varying in cell-wall composition were investigated. These properties were compared with levels of agglutinating antibodies and of specific IgG antibodies measured with an enzyme-linked immunosorbent assay (ELISA).

\section{MATERIALS AND METHODS}

Bacteria. E. coli $\mathrm{O} 75 \mathrm{~K}$ was isolated from the blood of a patient with septicaemia. It contained K antigen as measured by haemagglutination inhibition (van Dijk et al., 1979a); the $\mathrm{K}$ antigen was untypable. E. coli $\mathrm{F} 11$, which was isolated from the faeces of a healthy person, was untypable and did not contain $\mathrm{K}$ antigen as measured by haemagglutination inhibition. $E$. coli J5 a UDP-gal-epimerase deficient mutant (with lipopolysaccharide containing only core-glycolipid) and the parent strain O111B4 (with complete lipopolysaccharide) were kindly supplied by Dr B. Lugtenberg (Department of Microbiology and Molecular Biology, State University Utrecht, The Netherlands). Serotyping was done by $\operatorname{Dr}$ P. A. M. Guinee (Rijksinstituut voor de Volksgezondheid, Bilthoven, The Netherlands).

Immunisation. E. coli strains were grown overnight at $37^{\circ} \mathrm{C}$ in Mueller-Hinton broth, washed in phosphate-buffered saline (PBS) and suspended to a concentration of $10^{10}$ colony forming units (cfu)/ml in PBS. To prepare E. coli J5, O111B4, F11 and 075 vaccines, the bacteria were killed by heating for $30 \mathrm{~min}$ at $80^{\circ} \mathrm{C}$ and washed twice more in PBS. To raise $\mathrm{O} 75 \mathrm{~K}$ antiserum containing antibodies against both $\mathrm{O}$ and $\mathrm{K}$ antigens, the vaccine was prepared by formalin treatment of $E$. coli $\mathrm{O} 75 \mathrm{~K}$ suspension which leaves the $\mathrm{K}$ antigen intact (Kaijser and Ahlstedt, 1977). Vaccines were stored at $-70^{\circ} \mathrm{C}$ and thawed just before use. Four to six 1-kg New Zealand rabbits were subjected to the following intravenous immunisation schedule: day $1,0.1 \mathrm{ml}$; day $4,0.2 \mathrm{ml}$; day $7,0.3 \mathrm{ml}$; day $11,0.3 \mathrm{ml}$; day $14,0.4 \mathrm{ml}$; day 30 , $0.5 \mathrm{ml}$ of vaccine. One week after the last injection the rabbits were bled by heart puncture, serum was collected and stored in $1-\mathrm{ml}$ volumes at $-70^{\circ} \mathrm{C}$ until used. Normal rabbit serum was collected from five normal rabbits, pooled, and stored at $-70^{\circ} \mathrm{C}$. Serum samples were thawed shortly before use.

Absorption studies. $\mathrm{O} 75 \mathrm{~K}$ antiserum was absorbed with heat-killed $E$. coli $\mathrm{O} 75 \mathrm{~K}$ (without $\mathrm{K}$ antigen) and live $E$. coli $\mathrm{O} 75 \mathrm{~K}$ (with $\mathrm{K}$ antigen). Bacteria were grown in Mueller-Hinton broth, washed and suspended to $10^{11} \mathrm{cfu} / \mathrm{ml}$ in PBS. Part of the suspension was heated for 30 min at $80^{\circ} \mathrm{C}$ and washed again twice; $0.1 \mathrm{ml}$ of the heat-killed and $0.1 \mathrm{ml}$ of viable bacterial suspension were each incubated in $5 \mathrm{ml}$ of $075 \mathrm{~K}$ antiserum for $2 \mathrm{~h}$ at $37^{\circ} \mathrm{C}$. As a control, 5 $\mathrm{ml}$ of serum were incubated with $0.1 \mathrm{ml}$ of PBS. After incubation, serum samples were centrifuged for $25 \mathrm{~min}$ at $1600 \mathrm{~g}$. The supernate was used in opsonisation studies. 
Antibody titres in rabbit sera. Bacterial antibody titres were measured by the tube agglutination method (Campbell et al., 1970) and by ELISA modified from Rissing et al. (1978). Vinyl microtitre plates (Vinyl M25, Nutacon BV, 1172 N Schiphol, The Netherlands) were coated with $0.2 \mathrm{ml}$ of heated bacterial suspension containing $2.5 \times 10^{8}$ bacteria $/ \mathrm{ml}$ PBS, by incubation for $2 \mathrm{~h}$ at $37^{\circ} \mathrm{C}$. Unbound antigen was washed out and the plates were incubated for $1 \mathrm{~h}$ at $37^{\circ} \mathrm{C}$ with serial tenfold dilutions of serum which had been heated for 30 $\min$ at $56^{\circ} \mathrm{C}$. Unbound serum was removed by washing. As conjugate, $0.2 \mathrm{ml}$ of a 1 in 2000 dilution of goat peroxidase-labelled anti-rabbit IgG (Miles Yeda Ltd) was added to each cup. Plates were incubated for $2 \mathrm{~h}$ at $37^{\circ} \mathrm{C}$. The substrate was 2-amino-5-hydroxybenzoic acid (Merck-Schuchart, 8011 Hohenbrunn bei München), $80 \mathrm{mg} / 100 \mathrm{ml}$ in water containing $0.005 \% \mathrm{H}_{2} \mathrm{O}_{2}$. To each cup $0.2 \mathrm{ml}$ of the substrate was added, and plates were incubated for 1 $\mathrm{h}$ at $37^{\circ} \mathrm{C}$. The reaction was stopped by adding $50 \mu \mathrm{l} 1 \mathrm{~N} \mathrm{NaOH}$ to each cup. The ELISA titre was taken as the dilution that just gave a visible colour reaction as compared with the control incubated without serum.

Leucocytes. Isolation of polymorphonuclear leucocytes (PMN) from heparinised human normal donor blood was done by dextran sedimentation and centrifugation over a Ficoll isopaque gradient as previously described (Verbrugh et al., 1978).

Opsonisation assay. Bacterial opsonisation was measured in a quantitative phagocytosis system with ${ }^{3} \mathrm{H}$-thymidine radiolabelled $E$. coli and isolated PMNs as described previously (van Dijk et al., 1979b; Verbrugh et al., 1978). Briefly, $0.3 \mathrm{ml}$ of radioactive bacterial suspension containing $2.5 \times 10^{8} \mathrm{cfu} / \mathrm{ml}$ was incubated in $1.2 \mathrm{ml}$ of serum diluted with Hanks's balanced salt solution (HBSS). After incubation at $37^{\circ} \mathrm{C}$ the bacteria were washed by centrifugation for $15 \mathrm{~min}$ at $1600 \mathrm{~g}$ and were resuspended in $1.5 \mathrm{ml}$ of HBSS to obtain a final bacterial concentration of $5 \times 10^{6} \mathrm{cfu} / \mathrm{ml}$ Washed pre-opsonisation bacteria, $0.2 \mathrm{ml}$, were incubated with $0.2 \mathrm{ml} \mathrm{PMN} \mathrm{suspension} \mathrm{containing} 5 \times 10^{6} \mathrm{PMN} / \mathrm{m} 1 \mathrm{HBSS}$ in a $37^{\circ} \mathrm{C}$ shaking waterbath for $12 \mathrm{~min}$. Phagocytosis was stopped by adding $2.5 \mathrm{ml}$ of ice-cold PBS. Leucocyte-associated bacteria were then washed free from non-leucocyte-associated bacteria by three cycles of differential centrifugation for $5 \mathrm{~min}$ at $600 \mathrm{~g}$ and $4^{\circ} \mathrm{C}$. Leucocyte-associated radioactivity was measured in a liquid scintillation counter (Mark II, Nuclear Chicago, Chicago, Ill, USA) and expressed as a percentage of the total added radioactivity, i.e., percentage uptake of $E$. coli. Total added radioactivity was determined in one incubation mixture after centrifugation at $1600 \mathrm{~g}$ for $15 \mathrm{~min}$. E. coli taken up by PMN after incubation for 12 min was taken as a measure of bacterial opsonisation, i.e., as opsonic capacity of the serum sample.

Mouse-protection experiments. Swiss male albino mice 4-6 weeks old and weighing 15-20 $\mathrm{g}$ were used. LD50 measurements were made according to the method of Reed and Muench (1938). For protection studies $0.5 \mathrm{ml}$ of a 1 in 2 dilution of immune or normal rabbit serum heated for $30 \mathrm{~min}$ at $56^{\circ} \mathrm{C}$ was injected intraperitoneally just before intraperitoneal challenge with $0.5 \mathrm{ml}$ of a suspension containing $3 \times$ LD50 doses of live E. coli. Groups of mice consisted of seven animals. Protection studies were repeated two or three times. Percentages of survival after $48 \mathrm{~h}$ were calculated from all the experiments taken together.

\section{RESULTS}

\section{Antibody titres in rabbit sera}

Antibodies were raised in rabbits with heat-killed E. coli J5, O111B4, F11 and $\mathrm{O} 75 \mathrm{~K}$. Because heat treatment destroys the capsular $\mathrm{K}$ antigen, antibodies were also raised against formalin-treated $E$. coli $\mathrm{O} 75 \mathrm{~K}$ with intact $\mathrm{K}$ antigen. Antibody levels were measured by the ELISA technique (table I). Titres ranged from 6000 to 24000 . In O75 antiserum and in O75K antiserum high levels of specific IgG anti-O75 antibodies could be detected. The agglutination titres are also given in table I. Agglutinating antibodies 
TABLE I

Antibody titres in rabbit sera measured by ELISA and agglutination reaction

\begin{tabular}{|c|c|c|c|}
\hline \multirow[b]{2}{*}{ Antigen } & \multirow[b]{2}{*}{ Serum } & \multicolumn{2}{|c|}{$\begin{array}{l}\text { Antibody titre* } \\
\text { measured by }\end{array}$} \\
\hline & & ELISA & agglutination \\
\hline E. coli $\mathrm{J} 5 \dagger$ & $\begin{array}{l}\text { Anti J5 } \\
\text { NRS }\end{array}$ & $\begin{array}{r}12000 \\
200\end{array}$ & $\begin{array}{l}\text { NT } \\
\text { NT }\end{array}$ \\
\hline E. coli $\mathrm{O} 111 \mathrm{~B} 4 \dagger$ & $\begin{array}{l}\text { Anti O111B4 } \\
\text { NRS }\end{array}$ & $\begin{array}{r}6000 \\
100\end{array}$ & $\begin{array}{r}1280 \\
10\end{array}$ \\
\hline E. coli F11† & $\begin{array}{l}\text { Anti F11 } \\
\text { NRS }\end{array}$ & $\begin{array}{r}24000 \\
200\end{array}$ & $\begin{array}{r}2560 \\
10\end{array}$ \\
\hline E. coli $\mathrm{O} 75 \dagger$ & $\begin{array}{l}\text { Anti O75 } \\
\text { Anti O75K } \\
\text { NRS }\end{array}$ & $\begin{array}{r}24000 \\
24000 \\
200\end{array}$ & $\begin{array}{r}2560 \\
2560 \\
10\end{array}$ \\
\hline E. coli $\mathrm{O} 75 \mathrm{~K} \ddagger$ & $\begin{array}{l}\text { Anti O75 } \\
\text { Anti O75K } \\
\text { NRS }\end{array}$ & $\begin{array}{l}\text { NT } \\
\text { NT } \\
\text { NT }\end{array}$ & $\begin{array}{r}40 \\
160 \\
10\end{array}$ \\
\hline
\end{tabular}

* Titres are given as the serum dilution that gave a visible colour change in the ELISA reaction and just-visible agglutination in the agglutination reaction.

$\dagger$ Heat-killed bacteria as antigen.

$\ddagger$ Live bacteria as antigen

$\mathrm{NT}=$ not tested; $\mathrm{NRS}=$ normal rabbit serum.

could not be measured for $E$. coli $\mathrm{J} 5$ because this strain was auto-agglutinating. Specific agglutinating antibody titres measured with the respective heat-killed strain as antigen varied from 1280 to 2560 . In normal rabbit serum antibody titres were all low.

\section{Opsonic capacity of rabbit sera}

Uptake was not observed when bacteria were incubated in HBSS instead of serum. E. coli strains $\mathrm{J} 5, \mathrm{O} 111 \mathrm{~B} 4, \mathrm{~F} 11$ and $\mathrm{O} 75 \mathrm{~K}$ were effectively opsonised by 1 in 100,1 in 10, 1 in 20 and 1 in 5 dilutions of normal rabbit serum respectively (table II). All immune sera except the O75 antiserum, possessed a significantly better opsonic capacity for the corresponding strain than normal rabbit serum. The specific opsonins were heat stable. Heating

TABLE II

Opsonisation titres of rabbit sera

\begin{tabular}{l|rrrrrr}
\hline & \multicolumn{5}{|c}{ Opsonisation titre* of } \\
\cline { 2 - 7 } \multicolumn{1}{c|}{$\begin{array}{c}\text { Test } \\
\text { strain }\end{array}$} & NRS & anti & anti & Onti & anti & anti \\
& & & & F11 & O75 & O75K \\
\hline E. coli J5 & 100 & 1000 & 500 & 500 & 500 & 500 \\
E. coli O111B4 & 10 & 10 & 50 & 10 & 10 & 10 \\
E. coli F11 & 20 & 20 & 20 & 1000 & 20 & 20 \\
E. coli O75K & 5 & 5 & 5 & 5 & 5 & 20 \\
\hline
\end{tabular}

NRS $=$ normal rabbit serum.

${ }^{*}$ Given as the serum dilution that resulted in more than $50 \%$ phagocytosis. 
of the sera at $56^{\circ} \mathrm{C}$ for $30 \mathrm{~min}$ did not significantly alter their opsonisation titres, whereas heating of normal rabbit serum abolished opsonic activity. Cross-reacting opsonising antibodies could not be demonstrated in the rabbit antisera (table II).

The kinetics of opsonisation of E. coli O75K are shown in fig. 1. After 1 -min incubation of $E$. coli $\mathrm{O} 75 \mathrm{~K}$ in 1 in 5 diluted $\mathrm{O} 75$ antiserum, $60 \%$ of the

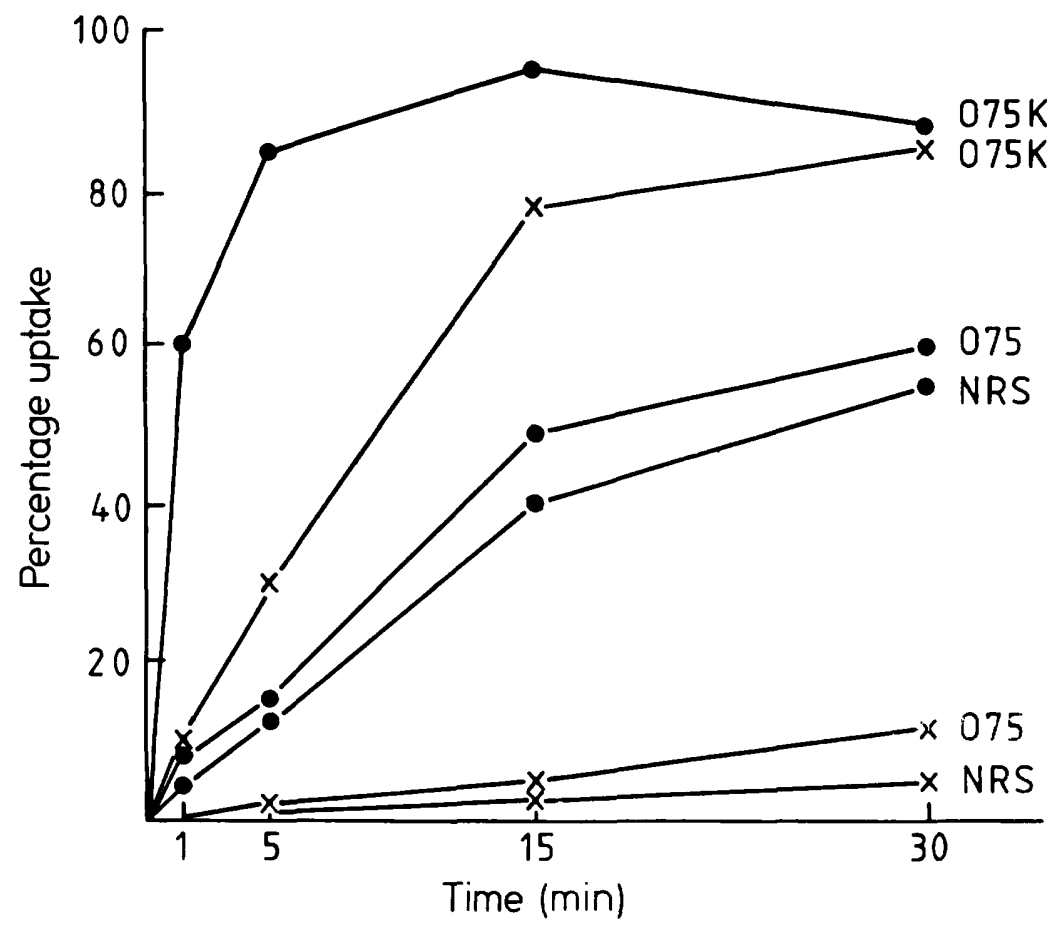

FIG. 1.-Kinetics of opsonisation of $E$. coli $\mathrm{O} 75 \mathrm{~K}$ in rabbit antiserum raised against the heat-treated strain $(\mathrm{O} 75)$, in rabbit antiserum raised against the formalin-treated strain (O75K) and in normal rabbit serum (NRS). - Represents phagocytosis by normal donor polymorphonuclear leucocytes after opsonisation for various times in unheated serum; $x-\times$ represents phagocytosis after opsonisation for various times in heated serum that had been heated at $56^{\circ} \mathrm{C}$ for $30 \mathrm{~min}$.

pre-opsonised bacteria had been taken up by the PMNs. Effective opsonisation in $\mathrm{O} 75$ antiserum occurred only after $30 \mathrm{~min}$. The efficient opsonisation of $E$. coli $\mathrm{O} 75 \mathrm{~K}$ in $\mathrm{O} 75 \mathrm{~K}$ antiserum suggested that $\mathrm{K}$ antibodies were necessary for effective phagocytosis. To test the importance of these antibodies for opsonisation, $\mathrm{O} 75 \mathrm{~K}$ antiserum was absorbed with heat-killed $E$. coli and with live $E$. coli $\mathrm{O} 75 \mathrm{~K}$. Only absorption with live bacteria abolished the opsonic capacity of the serum (fig. 2).

\section{Protective activity of rabbit antisera}

Antisera against strains $\mathrm{O} 111 \mathrm{~B} 4, \mathrm{~F} 11$ and $\mathrm{O} 75 \mathrm{~K}$ protected against 


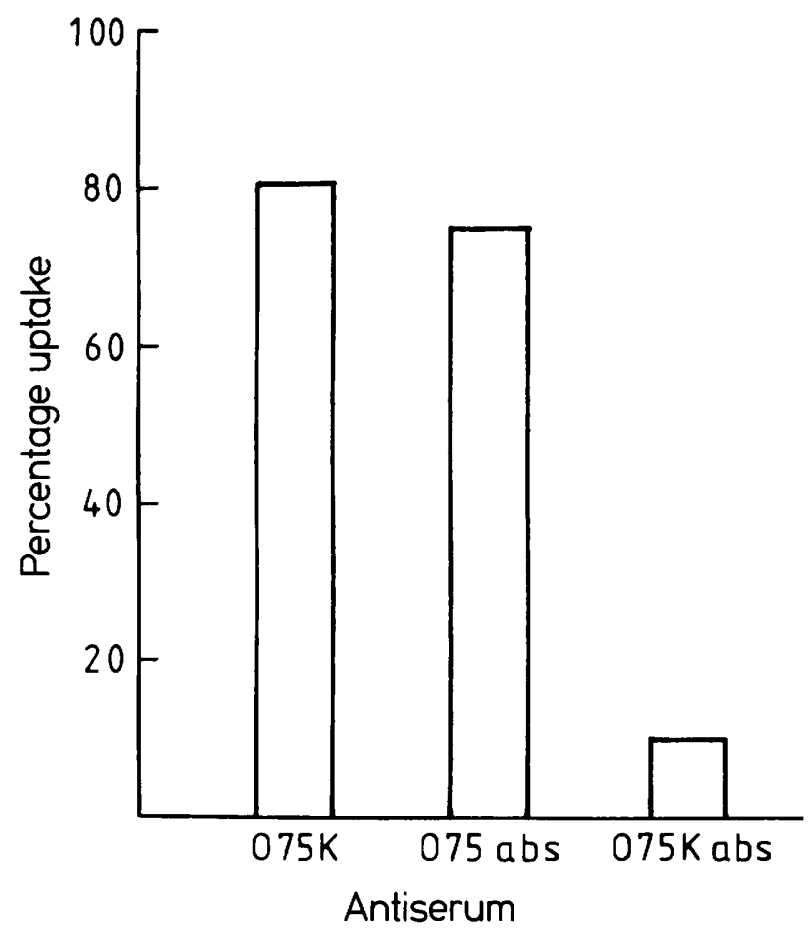

FIG. 2.-Phagocytosis of $E$. coli $\mathrm{O} 75 \mathrm{~K}$ after opsonisation in $\mathrm{O} 75 \mathrm{~K}$ antiserum unabsorbed (O75K), after absorption with heated $E$. coli $\mathrm{O} 75 \mathrm{~K}$ (O75 abs) and after absorption with live $E$. coli $\mathrm{O} 75 \mathrm{~K}$ (O75K abs).

challenge with the homologous strains but antisera against $\mathrm{O} 75$ and $\mathrm{J} 5$ did not protect against $075 \mathrm{~K}$ and $\mathrm{J} 5$ respectively. Cross-protective sera were not detected (table III).

TABLE III

Survival of mice passively immunised with rabbit sera after challenge with live E. coli

\begin{tabular}{|c|c|c|c|c|c|c|c|}
\hline \multirow[b]{2}{*}{$\begin{array}{l}\text { Challenge } \\
\text { strain }\end{array}$} & \multirow{2}{*}{$\begin{array}{l}\text { Number of cells } \\
\text { in } 3 \times \text { LD } 50 \\
\text { challenge dose }\end{array}$} & \multicolumn{6}{|c|}{$\begin{array}{l}\text { Percentage survival at } 48 \mathrm{~h} \text { after immunisation } \\
\text { with }\end{array}$} \\
\hline & & NRS & $\underset{\mathrm{J} 5}{\operatorname{anti}}$ & o111B4 & $\begin{array}{l}\text { anti } \\
\text { F11 }\end{array}$ & $\begin{array}{l}\text { anti } \\
\text { O75 }\end{array}$ & $\begin{array}{l}\text { anti } \\
\text { O75K }\end{array}$ \\
\hline $\begin{array}{l}\text { E. coli } \mathrm{J} 5 \\
\text { E. coli } \mathrm{O} 111 \mathrm{~B} 4 \\
\text { E. coli } \mathrm{F} 11 \\
\text { E. coli } \mathrm{O} 75 \mathrm{~K}\end{array}$ & $\begin{array}{l}2.7 \times 10^{10} \\
3.0 \times 10^{8} \\
2 \cdot 1 \times 10^{8} \\
3.0 \times 10^{7}\end{array}$ & $\begin{array}{r}0 \\
14 \\
0 \\
0\end{array}$ & $\begin{array}{r}14 \\
0 \\
0 \\
19\end{array}$ & $\begin{array}{r}0 \\
100 \\
0 \\
14\end{array}$ & $\begin{array}{l}0 \\
\text { NT } \\
100 \\
\text { NT }\end{array}$ & $\begin{array}{l}\text { NT } \\
\text { NT } \\
14 \\
14\end{array}$ & $\begin{array}{r}0 \\
15 \\
0 \\
100\end{array}$ \\
\hline
\end{tabular}

NRS = normal rabbit serum; NT $=$ not tested.

\section{Discussion}

In a previous study (van Dijk et al., 1979a) the amount of K antigen present could be correlated with resistance of the micro-organism to phago- 
cytosis. In the present study we found that in noncapsulate strains of $E$. coli the length of the $\mathrm{O}$-antigenic side chains determined opsonic requirements in normal rabbit serum. $E$. coli $\mathrm{J} 5$, a mutant of $E$. coli O111B4 lacking O-antigenic side chains was efficiently opsonised in 1 in 100 diluted serum, whereas 1 in 5 diluted serum was required to opsonise the parent strain O111B4.

After intravenous immunisation of rabbits with heat-killed bacteria, high-titre antisera, as measured by ELISA and agglutination, could be raised. These contained heat-stable opsonins specific for the corresponding non-K-antigen-bearing strain. Recent studies have shown that only antisera with specific antibodies against $\mathrm{K}$ antigens were opsonic for K1-containing and K92-containing E. coli strains (Welch et al., 1979; Welch and Stevens, 1979). These results were confirmed in the present study in which a strain with an untypable $\mathrm{K}$ antigen was used. This strain was used because it was isolated from a patient with $E$. coli septicaemia and because it was known that many strains isolated from the blood have untypable $\mathrm{K}$ antigens (McCabe et al., 1978). Only antisera containing antibodies against the $\mathrm{K}$ antigen were opsonic for the capsulate strain. When rabbits were immunised with heat-killed $E$. coli $\mathrm{O} 75 \mathrm{~K}$ lacking the heat-labile capsule, antibodies against the somatic O-antigen were raised as was determined by the ELISA method, but this serum was no more efficient at opsonising than normal rabbit serum. It is possible that anti-O antibodies are not opsonic for capsulate strains either because of an inability to penetrate the capsule or, if bound, because of an inability to interact with PMNs due to interference by surrounding capsular components.

The range of susceptibility to in-vitro phagocytosis of $E$. coli strains reflected differences in virulence. This confirms previous studies (Wolberg and DeWitt, 1969; Howard and Glynn, 1971). E. coli J5, a mutant lacking $\mathrm{O}$-antigenic side chains, was the least virulent. This strain is susceptible to the lytic action of serum (van Dijk et al., 1979a) and is effectively opsonised in 1 in 100 diluted serum. Therefore, after intraperitoneal injection, this strain may be cleared rapidly from the mouse peritoneal cavity by phagocytosis or lysis or both. Because $E$. coli $\mathrm{J} 5$ has a relatively high content of lipid A, the toxic substance of lipopolysaccharide, the lethal dose of $E$. coli J5 may be determined by its endotoxic activity rather than by its ability to escape phagocytosis.

The in-vivo protective ability of antiserum directed against outer-membrane and capsular components was examined in mice challenged with noncapsulate strains and $E$. coli $\mathrm{O} 75 \mathrm{~K}$. The anti-O sera raised against the noncapsulate $E$. coli strains proved to be protective against a challenge with the corresponding live $E$. coli strains. As with in-vitro phagocytosis studies, only antiserum raised against the $\mathrm{K}$-antigen-bearing strain was protective against a challenge with live $E$. coli $\mathrm{O} 75 \mathrm{~K}$. The lack of protection observed with $\mathrm{O} 75$ antiserum and with core-glycolipid antiserum (J5 antiserum) is in agreement with the results of others (Mullan et al., 1974; $\mathrm{Ng}$ et al., 1976; Greisman, Du Buy and Woodward, 1978; Welch et al., 1979). However, in 
addition to capsular antibodies it has been reported that $\mathrm{O}$ antisera, core-glycolipid antisera and lipid A antiserum protect animals against challenge with E. coli (Wolberg and DeWitt, 1969; Galanos, Lüderitz and Westphal, 1971; Kaijser et al., 1972; McCabe, 1972). In contrast to studies by Braude et al., (1973) and Ziegler et al., (1973), antiserum raised against $E$. coli J5 was not protective in mice challenged with capsulate and noncapsulate strains of $E$. coli. Moreover, protection was not observed against challenge with three times the LD50 of E. coli J5. Also Ng et al. (1976) and Greisman et al. (1978) were unable to demonstrate protection by antisera against rough mutants. Recently Peter et al. (1980) suggested that the challenge dose given to mice after passive immunisation with $\mathrm{J} 5$ antiserum affects the outcome of infection. The difference in the results might also be due to the mice that were used. We used Swiss mice whereas McCabe (1972) used CF1 mice and Young et al., (1975) used CB mice. Greisman et al., (1978) suggested that differences in protection could partly be explained by failure to use pre-immune serum from the same rabbit as the control. They found that normal rabbit and horse sera protected mice against various gram-negative challenge strains. However, we did not observe protection by serum pooled from five normal rabbits.

Another possible explanation for the controversy regarding the protective value of anti-core-glycolipid sera (J5 antiserum) is the use of different strains of E. coli. It is possible that the protective capacity of the sera is conferred only against a variety of noncapsulate strains, and that when more virulent challenge strains are used, protection is not observed (Welch et al., 1979). Data on protection against $E$. coli infections by antibodies are still inconclusive; careful dose-related protection and opsonisation studies with a wide variety of $E$. coli strains are required.

\section{REFERENCES}

Braude, A. I., Douglas, H. and Davis, C. E. 1973. Treatment and prevention of intravascular coagulation with antiserum to endotoxin. J. infect. Dis., 128 supplement, S157.

Campbell, D. H., Garvey, J. S., Cremer, N. E. and Sussdorf, D. H. 1970. Bacterial agglutination. In Methods in immunology, 2nd ed., W. A. Benjamin, Reading, Mass., p. 292.

Galanos, C., Lüderitz, O., AND WestPhal, O. 1971. Preparation and properties of antisera against the lipid-A component of bacterial lipopolysaccharides. Eur. J. Biochem., 24, 116.

Greisman, S. E., Du Buy, J. B. And Woodward, C. L. 1978. Experimental gram-negative bacterial sepsis. I. Reevaluation of the ability of rough mutant antisera to protect mice. Proc. Soc. exp. Biol. Med., 158, 482.

HowARD, C. J. AND GLYNN, A. A. 1971. The virulence for mice of strains of Escherichia coli related to the effects of $\mathrm{K}$ antigens on their resistance to phagocytosis and killing by complement. Immunology, 20, 767.

KAIJSER, B. 1973. Immunology of Escherichia coli: K antigen and its relation to urinary tract infection. J. infect. Dis., 127, 670.

KAIJSER, B. AND AHLSTEDT, S. 1977. Protective capacity of antibodies against Escherichia coli $\mathrm{O}$ and $\mathrm{K}$ antigens. Infect. Immun., 17, 286. 
Kaijser, B., Hanson, L. A., Jodal, U., Lidin-Janson, G. and Robbins, J. B. 1977. Frequency of $E$. coli $\mathrm{K}$ antigens in urinary tract infections in children. Lancet, 1, 663.

KaIJSER, B., Holmgren, J. AND Hanson, L. $\AA .1972$. The protective effect against $E$. coli of $\mathrm{O}$ and $\mathrm{K}$ antibodies of different immunoglobulin classes. Scand. J. Immun., 1, 27.

MCCABE, W. R. 1972. Immunization with R mutant of S. minnesota. 1: protection against challenge with heterologous gram-negative bacilli. J. Immun., 108, 601 .

McCabe, W. R., Carling, P. C., Bruins, S. and Greely, A. 1975. The relation of $\mathrm{K}$-antigen to virulence of Escherichia coli. J. infect. Dis., 131, 6.

McCabe, W. R., Kaijser, B., Olling, S., Uwaydah, M. and Hanson L. A. 1978. Escherichia coli in bacteremia: $\mathrm{K}$ and $\mathrm{O}$ antigens and serum sensitivity of strains from adults and neonates. J. infect Dis., 138, 33.

Mullan, N. A., Newsome, P. M., Cunnington, P. G., Palmer, G. H. and Wilson, M. E. 1974. Protection against gram-negative infections with antiserum to lipid $\mathrm{A}$ from Salmonella minnesota R595. Infect. Immun., 10, 1195.

Ng, A.-K., Chen, C. H., Chang, C.-M. And Nowotny, A. 1976. Relationship of structure to function in bacterial endotoxins: serologically cross-reactive components and their effect on protection of mice against some gram-negative infections. J. gen. Microbiol., 94, 107.

Peter, G., Chernow, M., Hastay, M. E., Ryff, J. C. and Zinner, S. H. 1980. Variable protective effect of core glycolipid (GCL) antisera in murine gram-negative bacteremia. In Abstracts from international symposium on infections in the immunocompromised host. Veldhoven, The Netherlands, abstract 128, p. 94.

REED, L. J. AND MUENCH, H. 1938. A simple method of estimating fifty per cent end points. Am. J. Hyg., 27, 493.

Rissing, J. P., Buxton, T. B., Moore, W. L., Ozawa, T. and Moore, W. L. 1978. Enzyme linked immunospecific antibody test for detecting antibody to Klebsiella. J. clin. Microbiol., 8, 704.

Robbins, J. B., McCracken, G. H., Gotschlich, E. C., Ørskov, F., Ørskov, I. and HANSON, L. A. 1974. Escherichia coli K1 capsular polysaccharide associated with neonatal meningitis. New Engl. J. Med., 290, 1216.

Van Dijk, W. C., Verbrugh, H. A., Peters, R., van der Tol, M. E., Peterson, P. K. and VERHOEF, J. 1979a. Escherichia coli K-antigen in relation to serum-induced lysis and phagocytosis. J. med. Microbiol., 12, 123.

Van Dijk, W. C., Verbrugh, H. A., van Der Tol, M. E., Peters, R. and Verhoef, J. $1979 b$. Role of Escherichia coli $\mathrm{K}$ capsular antigens during complement activation, $\mathrm{C} 3$ fixation and opsonization. Infect. Immun., 25, 603.

Verbrugh, H. A., Peters, R., Peterson, P. K. and Verhoef, J. 1978. Phagocytosis and killing of staphylococci by human polymorphonuclear and mononuclear leucocytes. $J$. clin Path., 31, 539.

Welch, W. D. AND Stevens, P. 1979. Serum requirements necessary for the opsonophagocytosis of Escherichia coli O73K92H1. Current Microbiol., 2, 245.

Welch, W. D., Martin, W. J., Stevens, P. and Young, L. S. 1979. Relative opsonic and protective activities of antibodies against $\mathrm{K} 1, \mathrm{O}$ and lipid-A antigens of Escherichia coli. Scand. J. infect. Dis., 11, 291.

WOLBERG, G. AND DEWITt, C.W. 1969. Mouse virulence of K (L) antigen containing strains of Escherichia coli. J. Bact., 100, 730.

Young, L. S., STEVens, P. AND INGRAM, J. 1975. Functional role of antibody against "core" glycolipid of enterobacteriaceae. J. clin. Invest., 56, 850.

Ziegler, E. J., Douglas, H., Sherman, J. E., Davis, C. E. and Braude, A. I. 1973. Treatment of $E$. coli and Klebsiella bacteremia in agranulocytic animals with antiserum to a UDP-gal epimerase-deficient mutant. J. Immun., 111, 433. 